DOI:http://doi.org/10.31617/k.knute.2019-03-19.33

\title{
СТРАТЕГІЇ ПОЗИЦІОНУВАННЯ БРЕНДУ
}

\author{
Данілова Л. Л. \\ к.е.н., доцент \\ кафедра маркетингу \\ Марчук А. \\ студент 3 курсу \\ ФЕМП \\ Київський національний торговельно-економічний університет, \\ Украӥна
}

Ключові слова: стратегія, позиціювання, бренд, стартап, стартап - індустрія, конкурентне позиціювання, позиціювання категорії, позиціювання за споживачами, позиціювання з точки зору престижу.

Keywords: strategy, positioning, brand, startup, startup - industry, competitive positioning, positioning of the category, positioning for consumers, positioning in terms of prestige.

Щороку в Україні зростає кількість інноваційних ідей та прогресивних людей, які готові втілювати ці ідеї. Згідно з рейтингом країн 2018 року за кількістю стартапів, складеним сервісом Startup Ranking, Україна займає 43 місце у світі (зі 286) із показником в 229 стартапів [9].

Збільшувалась і кількість українських стартапів, які отримали міжнародне визнання. Серед них - Prometheus, TripMyDream, Preply, PetCube, iBlazr, Delfast, Ecois.me, MyHelix, Competera, Augmented Pixels [6].

Україна завжди була країною, де розробляється та впроваджується в життя багато нових рішень, проте тільки невелика кількість розробок (приблизно 5-7 відсотків) втілюється в життя. Однією з причин такого становища $\epsilon$ те, що бізнесмени не завжди бажають витрачати гроші на вивчення потреб споживачів в новій продукції та послугах, інструментам просування новинок на ринок, їх позиціюванню.

В останні часи багато вчених досліджують питання створення стартап-проектів, розвитку стартап-індустріi, проте їх маркетинговому забезпеченню приділяється недостатньо уваги.

Проте, такі вчені, як Е. Райс та С. Бланк наголошують, що функції бізнесу й маркетингу стартапу є не менш важливими, ніж технології та розробка продукту, а тому їх повинна спрямовувати не менш чітка методологія [7]. 
К-С. Джонсон, науковець зі Сполучених Штатів Америки, відзначає, що маркетинговий компонент повинен бути обов'язково включений до бізнес-плану стартапу [4].

Дуже важливим є правильно представити товар чи послугу на ринку. Як відомо, позиціювання - це розробка такого образу бренду, що дає можливість закріпити його позиції на ринку. Головна мета позиціювання - диференціювати свої товари та послуги від товарів та послуг конкурентів.. Позиціювання допомагає підкреслити індивідуальність бренду.

Розглянемо стратегії позиціювання бренду, що $€$ найбільш поширеними.

1. Конкурентне позиціювання. В основі такої стратегії протиставлення бренду конкуренту, у якого планується відвоювати частку ринку. Прикладом може бути компанія, що виготовляе напої «7uр». Вона вирішила диференціювати свої напої від виробників газованих напоїв, в тому числі і Coca-Cola, по стратегії «не-кола». Споживач, який не хоче купувати колу, буде на підсвідомому рівні вибирати «не-колу» - «7ир».

2. Позиціювання категорії. При розробці позиціювання бренду в певній категорії, маркетингова кампанія акцентується на просуванні бренду як лідера в конкретній товарній категорії. Ця стратегія особливо вигідно використовується при створенні нового ринку. Прикладом може бути ринок електромобілів. В 2012 р. електромобілі були представлені машинами економ-сегменту (25-35 тис. дол.). Tesla Motors створила нову нішу електромобілів преміям-класу, продаючи Model S за ціною від \$ 75.000. Це відкрило ринок електрокарів для більш забезпечених споживачів.

3. Позиціювання за споживачами. В даному випадку позиціювання $\epsilon$ можливим, якщо рекламна кампанія акцентує увагу на конкретної цільової аудиторії. У рекламі такого бренду товар асоціюють 3 певним класом покупців, використовуючи фрази «створений для ...», «для тих, хто ...». Прикладами є: «ПриватБанк - банк для тих, хто любить Україну!»; Lenovo: «For those, who do» ( «Для тих, хто робить»).

4. Позиціювання по вигоді. Цей вид позиціювання бренду може будуватися як на емоційних, так і на раціональних вигодах. Позиціювання має давати однозначну відповідь на питання покупця: «Що я отримаю, вибираючи цей бренд?».Прикладами є: Honda i Toyota робили акцент на економічності і надійності своїх машин;Volvo упор на безпеку і довговічність; Nike часто грає на емоційних вигодах споживачів. Кампанія «Write the future» розробила такі слогани:Play to be remembered (Грай, щоб тебе запам'ятали). 
5. Позиціювання $з$ точки зору престижу. На відміну від щастя, престиж легко можна купити - завжди є люди, готові заплатити за особливе ставлення до себе, можливість побути VIP. Таке позиціювання підходить для компаній, які випускають по-справжньому люксові або преміальні товари. Це не обмежується коштовностями i дорогими автомобілями, і може поширюватися на продукти харчування і товари повсякденного попиту. Існує ряд стереотипних думок 3 приводу престижу: якщо парфуми, то Chanel; якщо прикраси, то Tiffany; якщо весільну сукню, то Vera Wang; якщо ручки, то Parker;якщо годинник, то Rolex.

Отже, правильне позиціювання товару або послуги завжди привертає увагу і дає можливість закріпитися на ринку, а згодом i стати брендом.

\section{Список використаних джерел}

1. Бернет Дж. Маркетинговые коммуникации. Интегрированный подход / Дж. Бернет, С. Мориарти ; пер. с англ. Н. Габенов, В. Кузин. - СПб. и др. : Питер, 2011. - 545 с.

2. Гудыма Э. Makeyourbrandvisibleagain: Как не тратить маркетингове бюджеты попусту / Э. Гудыма [Електронний ресурс]. - Режим доступу : http://mmr.ua/show/make_your_brand_visible__again_ remarketing_2018

3. Джоунс Дж. Роль рекламы в создании сильных брендов / Дж. Джоунс. - М. : Вильямс ИД - $2005-235$ с.

4. Ромат Е. Реклама : учеб. для вузов / Е. Ромат, Д. Сендеров. 8-е изд. - СПб. : Питер, 2013. - 512 с. - (Стандарт третьего поколения).

5. Соціальна відповідальність українського бізнесу: результати опитування [Електроний ресурс]. - Режим доступу : http://pmguinfo.dp.ua/ images/documents/korp_otnosheniya/soc_otvetstv.pdf

6. Цифрова незалежність. 10 найяскравіших українських стартапів останніх років [Електронний ресурс]. - Режим доступу : https://nv.ua/ukr/techno/itindustry/tsifrova-nezalezhnist-10-najjaskravishikh-ukrajinskikh-startapivostannikh-rokiv-2490377.html

7. Ries E. The lean startup: How today's entrepreneurs use continuous innovation to create radically successful businesses / Eric Ries. - New York, NY : Crown Business, 2011. - 296 p.

8. Marketing Plans for New Small-Business [Електронний ресурс] / Ventures Houston Chronicle. - Режим доступу : http://smallbusiness. chron.com/marketing-plans-new-smallbusiness-ventures-61029.html

9. Startup Ranking. Countries Ranking [Електронний ресурс]. - Режим доступу : http://www.startupranking.com/countries 